\title{
An Examination Of Occupational Differences In The Returns To Labor Market Experience
}

Paul E. Gabriel, (E-mail: pgabrie@luc.edu), Loyola University Chicago Susanne Schmitz, (E-mail: susans@elmhurst.edu), Elmhurst College

\begin{abstract}
This study explores differences in the returns to labor market experience for men across occupational categories in the U.S. labor market. Our analysis of data from the 2003 Current Population Survey indicates that an additional year of labor market experience has a significant and positive impact on the weekly earnings of white- and blue-collar workers. However, white-collar workers in general earn higher estimated returns to experience than their blue-collar counterparts, and these differences appear to be statistically significant.
\end{abstract}

\section{Introduction}

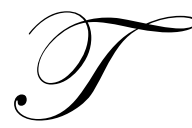

here is a well-established theoretical and empirical link between a worker's earnings potential and the endeavors that enhance his or her skills, training and experience. One such endeavor is the acquisition of additional skills through on-the-job training (OJT). In theory, on-the-job training leads to higher earnings potential because of higher worker productivity gained by virtue of general or specific skills learned on the job. The early theoretical and empirical work in human capital analysis (Schultz (1963), Hansen (1963), Becker (1964), and Mincer (1974)) demonstrated that the acquisition of labor market skills through on-thejob training is of comparable importance in the determination of earnings as schooling, migration, or other forms of human capital investments. Mincer's work was one of the first attempts to formalize the empirical link between onthe-job training, labor market experience, and the earnings potential of labor. Since these early human capital studies, a vast literature has developed which explores the labor market returns to on-the-job training.

Empirically, a worker's labor market experience is assumed to be a suitable proxy variable for the extent of on-the-job training. Labor market experience is generally found to be positively related to earnings, although these correlations vary by race, gender, and ethnicity. One issue that has received less attention in the literature is the extent to which there are variations in the returns to labor market experience across occupations.

Recent empirical work by Marcotte (2000) has found a statistical link between the growth of labor market inequality and differences in the acquisition of and returns to on-the-job training. Marcotte's study finds workers with more education also tend to receive greater levels of employer-sponsored training. Thus, earnings differentials between highly-educated, highly-paid workers, and those with less education and earnings increase over time due to the disparity in the acquisition of and returns to training. Groot and Mekkelhot's (1995) study of European workers also reports that returns to on-the-job training increase with the level of education. In a similar vein, the Dual Labor Market hypothesis of Doeringer and Piore (1971) suggests that occupations in the blue-collar sector are more likely to have unstable employment conditions, few opportunities for advancement, and offer little, if any, financial rewards to additional training. The implication of this line of research is that the returns to labor market experience may be skewed towards higher-paying professional occupations. Thus, there is a possibility that the link between earnings and work experience in occupations with lower levels of education, such as traditional blue-collar occupations, may be weaker than that for white-collar occupations. One way to address this issue is to pose a straight-forward empirical question: do blue-collar workers receive lower financial benefits to acquiring additional years of work 
experience than do white-collar workers? To investigate this question, we analyze recent data from the Current Population Survey to estimate rates of return to experience across occupational categories in the U.S. labor market.

\section{Earnings Model and Data}

Using a standard human capital earnings function (Mincer, 1974), we assume that a worker's earnings can be expressed as follows:

$$
\ln \mathrm{W}=\alpha \mathrm{SCHOOL}+\beta \mathrm{EXPER}-\delta(\text { EXPER })^{2}+\theta \mathrm{X}+\varepsilon
$$

where the dependent variable, $\ln \mathrm{W}$, is the logarithm of weekly earnings, SCHOOL denotes years of schooling completed, EXPER is years of potential labor market experience (measured as Age - SCHOOL - 5), (EXPER) ${ }^{2}$ is the quadratic experience term, $\mathrm{X}$ is a set of additional characteristics that are linked to earnings, and $\varepsilon$ is the stochastic error term. The presence of the quadratic experience term in (1) is based on the premise that crosssectional experience-earnings profiles tend to be concave, reflecting the possibility of diminishing marginal returns.

The estimated coefficients on experience, $\hat{\beta}$ and $\hat{\delta}$, can be used to estimate the percentage wage differential associated with one additional year of potential labor market experience. ${ }^{2}$ One difficulty with potential experience is that it assumes implicitly that a worker participates continuously in the labor force once they complete their formal schooling. However, since women tend to experience higher rates of intermittent or part-time labor market activity than men, potential experience is a less accurate proxy of their actual labor market experience. In general, since potential experience tends to be a better proxy for measuring male labor market experience (see Blau and Kahn, 1997; and Gabriel, 2004), we restrict our empirical analysis to men.

Empirical estimates of expression (1) often include dummy variables for occupation, which assumes implicitly that the returns to experience are constant across occupations. To address directly the potential variation in occupational rates of return to experience, we instead estimate expression (1) separately across occupational categories.

Our sample of male workers is taken from the March 2003 Annual Demographic file of the U.S. Current Population Survey (CPS). The CPS data provide a large, representative cross-sectional sample of workers in the U.S. labor market. Our sample includes non-agricultural workers with positive weekly earnings, who were not in the military, or enrolled in school. The aggregate occupational categories are listed in Table 1. For convenience, the categories are designated as either "blue-" or "white-collar" occupations. The variables included in the human capital earnings function (1) are listed in Table 2.

\section{Empirical Results}

The estimated occupational returns to labor market experience, and the estimated impact of an additional year of experience on weekly earnings, appear in Table 3. Also shown are OLS estimates for the relevant experience coefficients. $^{2}$ Our results indicate that there are positive and significant monetary rewards to experience across occupations, and that the returns to experience are consistent with a concave experience-earnings profile. The rates of return to experience range from $1.5 \%$ for the installation and maintenance occupations to $3.7 \%$ for the professional and technical fields. Overall, the average return is $3.24 \%$ in white-collar occupations and $2.25 \%$ in blue-collar occupations, and this difference is statistically significant at conventional levels. ${ }^{3}$ Although white-collar occupations tend to have higher estimated returns to experience, all workers accrue monetary rewards to additional labor market experience, regardless of occupation. One explanation for the lower marginal rates of return for bluecollar jobs is that these workers are older, and have acquired more experience than most white-collar workers, with the exception of managers. Thus, blue-collar workers tend to be further along their concave experience-earnings profiles, with the resulting declines in marginal rates of return to experience. However, if we apply the higher average experience level of blue-collar workers (21.71) to the white-collar coefficients, there is still a statistically 
significant white-collar advantage in estimated returns. ${ }^{4}$ Thus, the higher average experience of blue-collar workers cannot explain their lower estimated marginal returns to experience.

\section{Table 1 Variables for the Human Capital Wage Equation}

\section{Dependent Variable:}

LnW: Logarithm of weekly wage and salary earnings

Independent Variables $(X)$ :

Human Capital Variables:

SCHOOL: $\quad$ Years of schooling completed

EXPER: $\quad$ Years of "potential" labor market experience: (Age - SCHOOL -5$)$

EXPERSQ: $\quad(\text { EXPER })^{2}$

Demographic Variables and Other Earnings-related Traits:

UNION: $\quad$ set equal to 1 if an individual reports that his/her workplace is covered by a collective bargaining agreement, 0 otherwise

MSP: $\quad$ set equal to 1 if an individual is married, with spouse present, 0 otherwise

BLACK: $\quad$ set equal to 1 if an individual is black, non-Hispanic, 0 otherwise

HISPANIC: $\quad$ set equal to 1 if an individual is Hispanic, 0 otherwise

FTIME: $\quad$ set equal to 1 if an individual works 35 or more hours per week, 0 otherwise

NEAST: $\quad$ set equal to 1 if an individual lives in the Northeast census region, 0 otherwise

MWEST: $\quad$ set equal to 1 if an individual lives in the Midwest census region, 0 otherwise

WEST: $\quad$ set equal to 1 if an individual lives in the West census region, 0 otherwise (omitted category from wage regressions)

SOUTH: $\quad$ set equal to 1 if an individual lives in the South census region, 0 otherwise

METRO set equal to 1 if an individual lives in a metropolitan area, 0 otherwise

Table 2 Aggregate Occupational Categories

2003 Current Population Survey, Annual Demographic File

Blue Collar Occupations:

Maintenance

Operatives

Production

Construction

White Collar Occupations:

Service

Clerical

Sales

Managerial

Professional
Equipment Cleaners, Laborers and Repair Occupations

Machine Operators, Inspectors, Material Moving Occupations

Precision Production and Craft Occupations

Construction and Extractive Occupations
Service Occupations, including Private Household

Office and Administrative Support Occupations

Sales and Related Occupations

Executive, Administrative, and Managerial Occupations

Professional Specialty Occupations; Technicians and Related Support Occupations 
Table 3 Occupational Rates of Return to Labor Market Experience for Men U.S. Current Population Survey: March 2003 Annual Demographic

Occupation

White-collar Occupations:

Managerial
Professional
Sales
Clerical
Service

White-collar Average

\begin{tabular}{|c|c|c|c|}
\hline OLS & $\begin{array}{c}\text { OLS } \\
\text { Coefficient }\end{array}$ & & $\begin{array}{c}\text { Rate of } \\
\text { Return To }\end{array}$ \\
\hline $\begin{array}{l}\text { Coefficient } \\
\text { on EXPER }\end{array}$ & $\begin{array}{c}\text { on } \\
\text { EXPERSQ }\end{array}$ & $\begin{array}{c}\text { Average } \\
\text { Experience }\end{array}$ & $\begin{array}{c}\text { Experience } \\
(\%)\end{array}$ \\
\hline
\end{tabular}

$\begin{array}{ll}0.0548^{\mathrm{a}} & -0.0009^{\mathrm{a}} \\ 0.0554^{\mathrm{a}} & -0.0010^{\mathrm{a}} \\ 0.0532^{\mathrm{a}} & -0.0010^{\mathrm{a}} \\ 0.0341^{\mathrm{a}} & -0.0005^{\mathrm{a}} \\ 0.0448^{\mathrm{a}} & -0.0008^{\mathrm{a}}\end{array}$

22.32

18.63

19.16

18.53

19.13

19.55
$3.34 \%$

$3.67 \%$

$3.57 \%$

$2.57 \%$

$3.06 \%$

$3.24 \%$
Effect of 1 Additional Year Average Weekly of Experience on Earnings Weekly Earnings (\$)

Blue-collar Occupations:

Maintenance
Construction
Production
Transportation
operatives

Blue-collar Average

$\begin{array}{ccc} & 0.0228^{\mathrm{a}} & -0.0003^{\mathrm{b}} \\ & 0.0399^{\mathrm{a}} & -0.0007^{\mathrm{a}} \\ & 0.0287^{\mathrm{a}} & -0.0005^{\mathrm{a}} \\ & & \\ & 0.0438^{\mathrm{a}} & -0.0007^{\mathrm{a}}\end{array}$

21.94

20.29

22.54

22.06

$\begin{array}{ll}1.54 \% & \$ 713 \\ 2.66 \% & \$ 695 \\ 1.81 \% & \$ 623 \\ 2.97 \% & \$ 607 \\ \mathbf{2 . 2 5 \%} & \end{array}$

$\$ 41$

$\$ 40$

$\$ 27$

$\$ 16$

$\$ 16$

\section{Notes to Table 3:}

a, b Estimated OLS coefficient is statistically significant at the $1 \%$ level (a) or 5\% level (b).

\section{Notes}

1. The estimated return to experience is derived as follows: $e^{(\hat{\beta}+2 \hat{\delta} \text { EXPER })}-\mathbf{1}$, where EXPER is the average level of potential labor market experience.

2. The OLS occupational wage regression results are available from the authors upon request. The overall number of observations in the CPS sample is 7209. The appropriate sample weights are used in all empirical analyses.

3. The t-statistic (one-tailed test, small sample, unequal variances) for the white-collar, blue-collar difference in average returns is 2.81 , which is significant at the $3 \%$ level.

4. Applying the average blue-collar experience level to the white-collar experience coefficients results in a t-statistic of 2.43 for the white-collar, blue-collar difference in average returns, which is significant at the $5 \%$ level.

\section{Conclusion}

This study estimates occupational rates of return to labor market experience for men in the U. S. labor market. In particular, we investigate whether the positive link between earnings and experience applies to both white-collar and blue-collar occupations. Our analysis of data from the Current Population Survey supports the notion that an additional year of experience increases weekly earnings for both blue- and white-collar workers. An additional finding is that cross-sectional experience-earnings profiles are concave across all occupational categories. 
Our estimated occupational rates of return to experience range from 1.5 to 3.7 percent, with the highest average returns accruing to white-collar workers.

Our empirical results suggest that relative to their white-collar counterparts, blue-collar workers are at a disadvantage in terms of the financial returns to labor market experience. Given the limitations of the CPS data we can only speculate as to why blue-collar workers encounter lower returns to labor market experience than their white-collar colleagues. One possibility, suggested by Marcotte (2000), is that blue-collar workers receive less employer-sponsored on-the-job training than white-collar workers. In a similar vein, the Dual Labor Market Hypothesis of Doeringer and Piore (1971) contends that many blue-collar workers encounter unstable, unstructured employment conditions with limited opportunities for advancement or for the acquisition of additional marketable skills. Either of these possibilities, or a combination of them, would result in lower estimated returns for blue-collar workers.

\section{Suggestions for Future Research}

One avenue for future research may be to explore alternative data sets, perhaps at the individual firm level, that allow a more detailed analysis of the reasons why blue-collar workers receive lower rewards for acquiring additional labor market experience.

\section{References}

1. Becker, Gary S., Human Capital: A Theoretical and Empirical Analysis, with Special Reference to Education. New York: Columbia University Press, 1964.

2. Blau, Francine D.; Kahn, Lawrence M., "Swimming Upstream: Trends in the Gender Wage Differential in 1980s." Journal of Labor Economics Vol. 15 No. 3, pp. 1-42, 1997.

3. Doeringer, Peter B. and Michael J. Piore, Internal Labor Markets and Manpower Analysis. Armonk, NY: M. E. Sharpe, 1971.

4. Gabriel, Paul E. "An Empirical Comparison of Gender Differences in Labor Market Experience Measures.” Working Paper. Loyola University Chicago, School of Business Administration, 2004.

5. Groot, Wim and Eddie Mekkelholt, "The Rate of Return to Investments in On-the-job Training." Applied Economics Vol. 27, pp. 173-181, 1995.

6. Hansen, W. Lee, "Total and Private Rates of Return to Investment in Schooling." Journal of Political Economy Vo. 71, pp. 128-140, 1963.

7. Marcotte, Dave, "Continuing Education, Job Training, and Growth of Earnings Inequality." Industrial and Labor Relations Review, Vol. 53, pp. 602-623, 2000.

8. Mincer, Jacob, Schooling, Experience, and Earnings. New York: National Bureau of Economic Research, 1974.

9. Schultz, Theodore W., The Economic Value of Education. New York: Columbia University Press, 1963. 
Notes 